\title{
SHARP BOUNDS FOR SÁNDOR-YANG MEANS IN TERMS OF QUADRATIC MEAN
}

\author{
Hui-ZuO XU AND WEI-MAO QIAN
}

Abstract. In the article, we find the best possible parameters $\alpha, \beta, \lambda, \mu \in(1 / 2,1)$ such that the double inequalities

$$
\begin{gathered}
Q[\alpha a+(1-\alpha) b, \alpha b+(1-\alpha) a]<R_{Q A}(a, b)<Q[\beta a+(1-\beta) b, \beta b+(1-\beta) a], \\
Q[\lambda a+(1-\lambda) b, \lambda b+(1-\lambda) a]<R_{A Q}(a, b)<Q[\mu a+(1-\mu) b, \mu b+(1-\mu) a]
\end{gathered}
$$

hold for all $a, b>0$ with $a \neq b$, where $Q(a, b)=\sqrt{\left(a^{2}+b^{2}\right) / 2}$ is the quadratic mean, and $R_{Q A}(a, b)$ and $R_{A Q}(a, b)$ are two Sándor-Yang means.

Mathematics subject classification (2010): 26E60.

Keywords and phrases: Schwab-Borchardt mean, Sándor-Yang mean, arithmetic mean, quadratic mean.

\section{REFERENCES}

[1] E. Neuman And J. SÁndor, On the Schwab-Borchardt mean, Math. Pannon. 14, (2) (2003), 253266.

[2] A. WitKows KI, Interpolations of Schwab-Borchardt mean, Math. Inequal. Appl. 16, (1) (2013), 193 206.

[3] E. Neuman, On some means derived from the Schwab-Borchardt mean, J. Math. Inequal. 8, (1) (2014), 171-183.

[4] Z.-H. YANG AND Y.-M. CHU, Lazarević and Cusa type inequalities for hyperbolic functions with two parameters and their applications, J. Inequal. Appl. 2015, Article 403, (2015), 19 pages.

[5] Y.-Y. YANG, W.-M. QIAN AND Y.-M. CHU, Refinements of bounds for Neuman means with applications, J. Nonlinear Sci. Appl. 9, (4) (2016), 1529-1540.

[6] Y.-M. ChU, Y.-F. QIU, M.-K. WANG AND G.-D. WANG, The optimal convex combination bounds of arithmetic and harmonic means for the Seiffert's mean, J. Inequal. Appl. 2010, Article ID 436457, (2010), 7 pages.

[7] Y.-M. CHU, Y.-F. QIU AND M.-K. WANG, Sharp power mean bounds for the combination of Seiffert and geometric means, Abstr. Appl. Anal. 2010, Article ID 108920, (2010), 12 pages.

[8] Y.-M. ChU, M.-K. WANG AND Z.-K. WANG, An optimal double inequality between Seiffert and geometric means, J. Appl. Math. 2011, Article ID 261237, (2011), 6 pages.

[9] Y.-M. ChU, M.-K. WANG AND Z.-K. WANG, A best-possible double inequality between Seiffert and harmonic means, J. Inequal. Appl. 2011, Article 94, (2011), 7 pages.

[10] Y.-M. CHU, M.-K. WANG AND Z.-K. WANG, Best possible inequalities among harmonic, geometric, logarithmic and Seiffert means, Math. Inequal. Appl. 15, (2) (2012), 415-422.

[11] W.-M. Gong, Y.-Q. Song, M.-K. WANG AND Y.-M. ChU, A sharp double inequality between Seiffert, arithmetic, and geometric means, Abstr. Appl. Anal. 2012, Article ID 684834, (2012), 7 pages, 223-229.

[12] Y.-M. CHU, M.-K. WANG AND Y.-F. QIU, An optimal double inequality between power-type Heron and Seiffert means, J. Inequal. Appl. 2010, Article ID 146945, (2010), 11 pages.

[13] M.-K. WANG, Y.-F. QIU AND Y.-M. CHU, Sharp bounds for Seiffert means in terms of Lehmer means, J. Math. Inequal. 4, (4) (2010), 581-586. 
[14] Y.-M. Chu, M.-K. WAng And W.-M. Gong, Two sharp double inequalities for Seiffert mean, J. Inequal. Appl. 2011, Article 44, (2011), 7 pages.

[15] Y.-M. CHU, M.-K. WANG, S.-L. QIU AND Y.-F. QIU, Sharp generalized Seiffert mean bounds for Toader mean, Abstr. Appl. Anal. 2011, Article ID 605259, (2011), 8 pages.

[16] Y.-M. ChU, C. Zong AND G.-D. WANG, Optimal convex combination bounds of Seiffert and geometric means for the arithmetic mean, J. Math. Inequal. 5, (3) (2011), 429-434.

[17] Y.-M. CHU AND S.-W. Hou, Sharp bounds for Seiffert mean in terms of contraharmonic mean, Abstr. Appl. Anal. 2012, Article ID 425175, (2012), 6 pages.

[18] H.-N. HU, G.-Y. TU AND Y.-M. CHU, Optimal bounds for Seiffert mean in terms of one-parameter means, J. Appl. Math. 2012, Article ID 917120, (2012), 7 pages.

[19] Y.-M. LI, B.-Y. LiU AND Y.-M. CHU, Sharp bounds for the Neuman-Sándor mean in terms of generalized logarithmic mean, J. Math. Inequal. 6, (4) (2012), 567-577.

[20] Y.-M. CHU AND B.-Y. Long, Bounds of the Neuman-Sándor mean using power and identric means, Abstr. Appl. Anal. 2013, Article ID 832591, (2013), 6 pages.

[21] W.-F. XIA AND Y.-M. CHU, Optimal inequalities between Neuman-Sándor, centrodial and harmonic means, J. Math. Inequal. 7, (4) (2013), 593-600.

[22] Y.-M. ChU AND W.-F. XIA, Inequalities for generalized logarithmic means, J. Inequal. Appl. 2009, Article ID 763252, (2009), 7 pages.

[23] B.-Y. Long AND Y.-M. CHU, Optimal inequalities for generalized logarithmic, arithmetic, and geometric means, J. Inequal. Appl. 2010, Article 806825, (2010), 10 pages.

[24] Y.-M. CHU AND B.-Y. Long, Best possible inequalities between generalized logarithmic mean and classical means, Abstr. Appl. Anal. 2010, Article ID 303286, (2010), 13 pages.

[25] W.-F. XIA, Y.-M. CHU AND G.-D. WANG, The optimal upper and lower power mean bounds for a convex combination of the arithmetic and logarithmic means, Abstr. Appl. Anal. 2010, Article ID 604804, (2010), 9 pages.

[26] Y.-M. CHU AND W.-F. XIA, Two optimal double inequalities between power mean and logarithmic mean, Comput. Math. Appl. 60, (1) (2010), 83-89.

[27] Y.-M. CHU, S.-S. WANG AND C. ZONG, Optimal lower power mean bound for the convex combination of harmonic and logarithmic means, Abstr. Appl. Anal. 2011, Article ID 520648, (2011), 9 pages.

[28] Y.-F. QIU, M.-K. WANG, Y.-M. CHU AND G.-D. WANG, Two sharp inequalities for Lehmer mean, identric mean and logarithmic mean, J. Math. Inequal. 5, (3) (2011), 301-306.

[29] Z.-H. YANG, Y.-M. CHU AND Y.-Q. Song, Sharp bounds for Toader-Qi mean in terms of logarithmic and identric means, Math. Inequal. Appl. 19, (2) (2016), 721-730.

[30] W.-M. QIAN AND Y.-M. CHU, Best possible bounds for Yang mean using generalized logarithmic mean, Math. Probl. Eng. 2016, Article ID 8901258, (2016), 7 pages.

[31] M.-K. WAng, Y.-M. CHU, Y.-F. QIU AND S.-L. QIU, An optimal power mean inequality for the complete elliptic integrals, Appl. Math. Lett. 24, (6) (2011), 887-890.

[32] Y.-M. CHU, M.-K. WANG AND Y.-F. QIU, On Alzer and Qiu's conjecture for complete elliptic integral and inverse hyperbolic tangent function, Abstr. Appl. Anal. 2011, Article ID 697547, (2011), 7 pages.

[33] M.-K. WANG, Y.-M. ChU, S.-L. QIU AND Y.-P. JIANG, Convexity of the complete elliptic integrals of the first kind with respect to Hölder means, J. Math. Anal. Appl. 388, (2) (2012), 1141-1146.

[34] G.-D. WANG, X.-H. Zhang AND Y.-M. CHU, A power mean inequality involving the complete elliptic integrals, Rocky Mountain J. Math. 44, (5) (2014), 1661-1667.

[35] Z.-H. YANG AND Y.-M. CHU, A monotonicity property involving the generalized elliptic integrals of the first kind, Math. Inequal. Appl. 20, (3) (2017), 729-735.

[36] Z.-H. YANG, W. ZHANG AND Y.-M. CHU, Sharp Gautschi inequality for parameter $0<p<1$ with applications, Math. Inequal. Appl. 20, (4) (2017), 1107-1120.

[37] M.-K. WANG AND Y.-M. CHU, Landen inequalities for a class of hypergeometric functions with applications, Math. Inequal. Appl. 21, (2) (2018), 521-537.

[38] M.-K. WANG, S.-L. QIU AND Y.-M. CHU, Infinite series formula for Hübner upper bound function with applications to Hersch-Pfluger distortion function, Math. Inequal. Appl. 21, (3) (2018), 629-648.

[39] M.-K. WANG, Y.-M. Li AND Y.-M. CHU, Inequalities and infinite product formula for Ramanujan generalized modular equation function, Ramanujan J., doi : 10.1007/s11139-017-9888-3. 
[40] Y.-M. CHU AND M.-K. WANG, Optimal inequalities between harmonic, geometric, logarithmic, and arithmetic-geometric means, J. Appl. Math. 2011, Article ID 618929, (2011), 9 pages.

[41] Y.-M. CHU AND M.-K. WANG, Inequalities between arithmetic-geometric, Gini, and Toader means, Abstr. Appl. Anal. 2012, Article ID 830585, (2012), 11 pages.

[42] Y.-M. CHU AND M.-K. WANG, Optimal Lehmer mean bounds for the Toader mean, Results Math. 61, (3-4) (2012), 223-229.

[43] W.-M. QIAN AND Y.-M. CHU, Sharp bounds for a special quasi-arithmetic mean in terms of arithmetic and geometric means with two parameters, J. Inequal. Appl. 2017, Article 274, (2017), 10 pages.

[44] Z.-H. YANG, W.-M. QIAN, Y.-M. CHU AND W. ZHANG, On approximating the arithmeticgeometric mean and complete elliptic integral of the first kind, J. Math. Anal. Appl. 462, (2) (2018), 1714-1726.

[45] Y.-M. CHU, M.-K. WANG AND S.-L. QIU, Optimal combinations bounds of root-square and arithmetic means for Toader mean, Proc. Indian Acad. Sci. Math. Sci. 122, (1) (2012), 41-51.

[46] Y.-M. CHU, M.-K. WANG AND X.-Y. MA, Sharp bounds for Toader mean in terms of contraharmonic mean with applications, J. Math. Inequal. 7, (2) (2013), 161-166.

[47] W.-M. QIAN, X.-H. Zhang AND Y.-M. CHU, Sharp bounds for the Toader-Qi mean in terms of harmonic and geometric means, J. Math. Inequal. 11, (1) (2017), 121-127.

[48] M.-K. Wang, Y.-M. Chu, S.-L. QIU And Y.-P. JIAng, Generalized Hersch-Pfluger distortion function and complete elliptic integrals, J. Math. Anal. Appl. 385, (1) (2012), 221-229.

[49] Y.-M. CHU, M.-K. WANG, S.-L. QIU AND Y.-P. JIANG, Bounds for complete elliptic integrals of the second kind with applications, Comput. Math. Appl. 63, (7) (2012), 1177-1184.

[50] Y.-M. ChU, M.-K. WANG, Y.-P. JiAnG AND S.-L. QIU, Concavity of the complete elliptic integrals of the second kind with respect to Hölder means, J. Math. Anal. Appl. 395, (2) (2012), 637-642.

[51] Y.-M. CHU, Y.-F. QIU AND M.-K. WANG, Hölder mean inequalities for the complete integrals, Integral Transforms Spec. Funct. 23, (7) (2012), 521-527.

[52] M.-K. WANG AND Y.-M. CHU, Asymptotical bounds for complete elliptic integrals of the second kind, J. Math. Anal. Appl. 402, (1) (2013), 119-126.

[53] Z.-H. YANG, Y.-M. CHU AND W. ZHANG, Accurate approximations for the complete elliptic integral of the second kind, J. Math. Anal. Appl. 438, (2) (2016), 875-888.

[54] M.-K. WANG, Y.-M. CHU AND Y.-Q. Song, Asymptotical formulas for Gaussian and generalized hyperbolic functions, Appl. Math. Comput. 276, (2016), 44-60.

[55] M.-K. WANG AND Y.-M. CHU, Refinements of transformation inequalities for zero-balanced hypergeometric frunctions, Acta Math. Sci. 37B, (3) (2017), 607-622.

[56] Z.-H. YANG, Y.-M. CHU AND X.-H. ZHANG, Sharp Stolarsky mean bounds for the complete elliptic integral of the second kind, J. Nonlinear Sci. Appl. 10, (3) (2017), 929-936.

[57] Z.-H. YANG, W.-M. QIAN, Y.-M. CHU AND W. ZHANG, On approximating the error function, Math. Inequal. Appl. 21, (2) (2018), 469-479.

[58] E. Neuman, On a new family of bivariate means, J. Math. Inequal. 11, (3) (2017), 673-681.

[59] Z.-H. YANG, Three families of two-parameter means constructed by trigonometric functions, J. Inequal. Appl. 2013, Article 541, (2013), 27 pages. 